\title{
Gene-Environment Interactions: Lifetime Cognitive Activity, APOE Genotype, and Beta-Amyloid Burden
}

\author{
Miranka Wirth, ${ }^{1}$ Sylvia Villeneuve, ${ }^{1}$ 일 Renaud La Joie, ${ }^{1}$ Shawn M. Marks, ${ }^{1}$ and William J. Jagust ${ }^{1,2,3}$ \\ ${ }^{1}$ Helen Wills Neuroscience Institute and ${ }^{2}$ School of Public Health, University of California, Berkeley, California 94720 , and ${ }^{3}$ Life Sciences Division, Lawrence \\ Berkeley National Laboratory, Berkeley, California 94720
}

Carriers of the apolipoprotein E (APOE) $\varepsilon 4$ allele, the major genetic risk for Alzheimer's disease (AD), harbor an increased load of $\beta$-amyloid $(\mathrm{A} \beta)$ plaque burden that is felt to be a major instigator of AD development. Data has suggested that lifestyle factors may reduce $\mathrm{AD}$ risk by directly mitigating $\mathrm{A} \beta$ pathology, which could be particularly beneficial in APOE $\varepsilon 4$ carriers. We therefore examined the interaction between lifetime cognitive activity and the APOE $\varepsilon 4$ allele in relation to brain A $\beta$ burden. We obtained measures of lifetime cognitive activity in 118 cognitively normal human individuals (mean age: $76.13 \pm 5.56$ years, 70 women) using a validated questionnaire that included measures over early, middle, and current age epochs. Hierarchical regression models (adjusted for age, gender, and years of education) were conducted to examine effects of APOE $\varepsilon 4$ carrier status, lifetime cognitive activity, and the interaction of the two factors with cortical A $\beta$ deposition, quantified using $\left[{ }^{11} \mathrm{C}\right]$ Pittsburgh-compound-B (PIB)-PET. As expected, the $\varepsilon 4$ carriers exhibited higher PIB retention compared with noncarriers. Lifetime cognitive activity moderated the APOE genotype effect such that cortical PIB retention was diminished in $\varepsilon 4$ carriers that reported higher cognitive activity over the life course. The findings suggest that greater lifetime cognitive activity may forestall AD pathology, specifically in genetically susceptible individuals. The effect could imply that cognitive training promotes increased neural efficiency that might retard the lifelong neurally mediated deposition of $\mathrm{A} \beta$.

Key words: aging; Alzheimer's disease; APOE; $\beta$-amyloid; lifestyle activity; PIB-PET

\section{Introduction}

The $\beta$-amyloid $(\mathrm{A} \beta)$ protein, an Alzheimer's disease (AD) hallmark, can be found in aggregated forms in cognitively normal older adults. There it is proposed to incite a neurotoxic cascade that leads to neurodegeneration, cognitive decline, and eventually dementia (Jack et al., 2010). The lack of effective treatment necessitates the identification of factors that may forestall such $\mathrm{AD}$ pathology. The $\varepsilon 4$ variant of the apolipoprotein $\mathrm{E}$ (APOE) allele, the major genetic risk factor for AD (Farrer et al., 1997), is related to higher brain $\mathrm{A} \beta$ deposition (Reiman et al., 2009), as well as faster cognitive decline (Packard et al., 2007) in older people. This risk-related polymorphism thus offers the potential to target individuals at higher risk for dementia as well as to identify lifestyle factors that could modify the pathogenic mechanisms underlying these risks.

Participation in cognitively stimulating activities (e.g., playing games, reading books) has been shown to protect against cognitive decline (Wilson et al., 2012) and AD (Wilson et al., 2002b). In

\footnotetext{
Received Oct. 29, 2013; revised May 1, 2014; accepted May 19, 2014.

Author contributions: M.W. and W.J.J. designed research; M.W. and W.J.J. performed research; M.W., S.V., R.L.J., and S.M.M. analyzed data; M.W., S.V., and W.J.J. wrote the paper.

This research work was supported by NIH Grant AG034570, and the Swiss National Science Foundation Grant PA00P1-131515. We thank Grace Tang (UC Berkeley, behavioral data analysis support), Cindee Madison (UC Berkeley, neuroimaging data analysis support), and Jacob Vogel (UC Berkeley, data collection and discussion).

The authors declare no competing financial interests.

Correspondence should be addressed to Dr Miranka Wirth, Helen Wills Neuroscience Institute, 132 Barker Hall \#3190, University of California, Berkeley, CA 94720-3190. E-mail: miranka.wirth@gmail.com.

DOI:10.1523/JNEUROSCI.4612-13.2014

Copyright $\odot 2014$ the authors $\quad 0270-6474 / 14 / 348612-06 \$ 15.00 / 0$
}

fact, a recent analysis of modifiable risk factors emphasized that reducing cognitive inactivity throughout life could prevent millions of AD cases (Barnes and Yaffe, 2011). The APOE genotype may modify the relationships between lifestyle and dementia risk. There is evidence that cognitive engagement could be particularly protective against cognitive decline and dementia among APOE $\varepsilon 4$ carriers (Carlson et al., 2008; Niti et al., 2008), yet reports are inconsistent (Woodard et al., 2012). The findings imply that the relationship between lifetime cognitive activity and genotype may be important in establishing dementia risk.

The biological mechanisms underlying these possible genelifestyle interactions are unknown. Existing research suggests that lifestyle activities, such as greater lifetime cognitive activity, as well as more long-term physical activity, may reduce brain A $\beta$ burden (Liang et al., 2010; Landau et al., 2012). In the present study, we assessed whether associations of lifetime cognitive activity and brain $\mathrm{A} \beta$ deposition are modified by APOE status and whether higher cognitive engagement throughout life decreases $\mathrm{A} \beta$ burden, particularly in APOE $\varepsilon 4$ carriers. Brain $\mathrm{A} \beta$ deposition was measured in cognitively normal older adults using $\left[{ }^{11} \mathrm{C}\right]$ Pittsburgh-compound-B (PIB) positron emission tomography (PET). In the same individuals we measured cognitive activity over the life course using a previously validated questionnaire (Wilson et al., 2003). We hypothesized that greater lifetime cognitive activity would mitigate effects of the APOE $\varepsilon 4$ allele on $A \beta$ burden. Follow-up analyses examined, whether the expected advantageous effect was similarly detectable for different life epochs. 
Table 1. Characteristics for APOE $€ 4$ noncarriers and carriers groups

\begin{tabular}{lccc}
\hline & APOE $\epsilon 4$ noncarriers & APOE $\epsilon 4$ carriers & $p$ value \\
\hline Participants, no. (\%) & $85(72)$ & $33(28)$ & \\
Age at PIB, years (SD) & $76.72(5.80)$ & $74.59(4.63)$ & 0.06 \\
Women, no. (\%) & $50(59)$ & $20(61)$ & 1.00 \\
Education & $16.73(1.86)$ & $17.21(2.37)$ & 0.24 \\
MMSE, mean (SD) & $28.72(1.33)$ & $28.70(1.26)$ & 0.94 \\
Measurement characteristics & & & \\
$\Delta_{\text {time }}$ (NTS-MRI), years (SD) & $0.29(0.17)$ & $0.30(0.18)$ & 0.83 \\
$\Delta_{\text {time }}$ (NTS-PIB), years (SD) & $0.34(0.37)$ & $0.38(0.32)$ & 0.57 \\
$\quad \Delta_{\text {time }}$ (MRI-PIB), years (SD) & $0.13(0.33)$ & $0.14(0.35)$ & 0.83 \\
Cognitive activity & & & \\
$\quad$ Lifetime & $3.53(0.56)$ & $3.51(0.51)$ & 0.85 \\
$\quad$ Early life & $3.36(0.73)$ & $3.38(0.63)$ & 0.89 \\
$\quad$ Middle life & $3.68(0.57)$ & $3.55(0.47)$ & 0.23 \\
$\quad$ Current life & $3.88(0.56)$ & $3.85(0.64)$ & 0.76 \\
\hline
\end{tabular}

$p$ Values were estimated from parametric or nonparametric statistical comparisons.

$\Delta$, Difference; NTS, neuropsychological test session.

\section{Materials and Methods}

\section{Study participants}

One-hundred-eighteen cognitively normal older human individuals from the Berkeley Aging Cohort, an ongoing longitudinal study, were investigated. Eligibility criteria included a Geriatric Depression Scale (Yesavage et al., 1982) score $\leq 10$, Mini-mental state examination score (MMSE) $\geq 25$, normal memory functions (all scores within -1.5 SD of age- and education-adjusted norms), and age between 60 and 90 years. The subjects were on average 76.13 years of age ( $\mathrm{SD}=5.56), 70(59 \%)$ women, reported 16.86 (2.02) years of education and had a mean MMSE score of 28.71 (1.31). Each participant underwent standardized neuropsychological testing, and MRI and PIB-PET scanning. Subjects were free of serious neurological and psychiatric illnesses, except hyperlipidemia (46 cases, 39\%) and diabetes mellitus (7 cases, 6\%). Hypertension was present in $45(38 \%)$ cases, as measured using blood pressure recordings of the brachial artery (available in 112 cases) and defined as systolic blood pressure $\geq 140 \mathrm{mmHg}$ or diastolic blood pressure $\geq 90 \mathrm{mmHg}$. Written informed consent was obtained from each participant in accordance with the Institutional Review Boards of the University of California, Berkeley, and the Lawrence Berkeley National Laboratory (LBNL). The present sample included all 65 individuals from a previous publication (Landau et al., 2012) that only investigated associations of lifetime cognitive activity and cortical PIB retention.

\section{Assessment of cognitive activity}

From each participant, lifetime cognitive activity was obtained using a previously validated cognitive activity questionnaire (Wilson et al., 2003). In brief, a 25 -item interview was used, in which the frequency of common cognitively demanding activities, such as reading books, newspapers, and magazines, writing letters, going to the library, and playing games, was recorded across age epochs at year 6, 12, 18, and 40 (retrospectively), and at the current age. Responses were provided on a 5-point frequency scale ranging from 1 (once a year or less) to 5 (every day or almost every day). For each participant, we calculated the mean of each age epoch and created four cognitive activity measures: lifetime cognitive activity (average over all age epochs), early (average over the age epochs 6 , 12 , and 18), middle life (average over the age epoch 40), and current (average over the current age epoch) life. Age epoch-related cognitive activity measures were correlated (intraclass correlation coefficient; ICC $=0.72,95 \%$ CI: 0.63, 0.80). There were, however, significant differences across self-reported early life, middle life, and current cognitive activity, as examined using a repeated-measures $\operatorname{ANOVA}\left(F_{(2,234)}=\right.$ 38.13, $p<0.001)$.

Reliability of the scales was assessed in 75 participants who fully completed at least two cognitive activity interviews (mean interval 1.63 years, $\mathrm{SD}=0.50)$. The ICC for lifetime cognitive activity was high $(r=0.91$, 95\% CI: 0.86, 0.94), replicating earlier reports (Wilson et al., 2003). Reliability was also good for early life (ICC: $r=0.92,95 \%$ CI: $0.88,0.95$ ), middle life (ICC: $r=0.89,95 \%$ CI: 0.83, 0.93), and current (ICC: $r=$
0.79, 95\% CI: 0.67, 0.87) cognitive activity. Nonsignificant differences between first and second administration for early life (mean $=0.01,95 \%$ CI: $-0.08,0.09)$, middle life (mean $=0.01,95 \% \mathrm{CI}:-0.07,0.09)$, and current life (mean $=0.03,95 \% \mathrm{CI}$ : $-0.07,0.14)$ cognitive activity measures further supported temporal stability. There was no significant difference in the reproducibility of cognitive activity scores across age epochs, as indicated using a repeated-measures ANOVA (age epoch $\times$ administration: $\left.F_{(2,148)}=0.19, p=0.82\right)$.

\section{Assessment of covariates}

Additional variables (covariates) were assessed to control for potential bias or confounding effects. Perceived memory function, previously associated with regional A $\beta$ burden (Perrotin et al., 2012), was estimated by the average of two scales, participants' ratings of their memory ability in comparison with other age-matched people and their own memory ability 20 years ago, using a 4 -point scale from 1 (better) to 4 (much worse). Depression was measured using the Geriatric Depression Scale. Current physical activity was quantified using the modified Minnesota leisuretime activities questionnaire (Taylor et al., 1978; Geffken et al., 2001). Participants indicated frequency (over the last 2 weeks and months per year) and duration (time spent per session) of 15 leisure-time physical activities and any extra physical activity. Frequency and duration information were multiplied using an activity-specific intensity code indicating calorie expenditure (Taylor et al., 1978) and summed to represent intensity of physical activity (total kilocalories of energy expended) during the last year. Finally, the socioeconomic status was estimated from the participant's self-reported professional background, based on the 1990 occupation classification systems of the U.S. Bureau of the Census (Hauser and Warren, 1997).

\section{Acquisition and processing of the neuroimaging data}

MRI. The structural MRI scans were acquired at LBNL on a 1.5T Magnetom Avanto system (Siemens Medical Systems) using a 12-channel head-coil run in triple mode. High-resolution T1-weighted magnetization-prepared rapid gradient echo (MPRAGE) scans were collected axially with the following measurement parameters: TR $=2110 \mathrm{~ms}$, $\mathrm{TE}=3.58 \mathrm{~ms}$, flip angle $=15^{\circ}$, field-of-view $=256 \times 256 \mathrm{~mm}$, number of slices $=160$ with a $50 \%$ gap, voxel size $=1 \times 1 \times 1 \mathrm{~mm}^{3}$.

PIB-PET. The PIB-PET scans were collected at LBNL, with injection of $\sim 15 \mathrm{mCi}$ of the $\left[{ }^{11} \mathrm{C}\right]$ PIB tracer. The PIB-PET images of 93 subjects were acquired using an ECAT EXACT HR (Siemens) PET scanner and 25 subjects were studied with a Siemens Biograph PET/CT scanner. Dynamic acquisition frames were obtained in the $3 \mathrm{D}$ acquisition mode over a 90 min measurement interval $(4 \times 15 \mathrm{~s}$ frames, $8 \times 30 \mathrm{~s}$ frames, $9 \times 60 \mathrm{~s}$ frames, $2 \times 180 \mathrm{~s}$ frames, $8 \times 300 \mathrm{~s}$ frames, and $3 \times 600 \mathrm{~s}$ frames) after a 10 min transmission scan or CT. The data processing, described in detail previously (Wirth et al., 2013), used graphical analysis with a cerebellar gray reference region to construct distribution volume ratio (DVR) images (Logan et al., 1996).

The native-space PIB-PET (DVR) images were coregistered to the native-space MRI images for each participant. Global cortical PIB retention (representing cortical $\mathrm{A} \beta$ burden) was calculated by extracting a mean DVR value from frontal, temporal, parietal, and anterior/posterior cingulate ROIs using the automated FreeSurfer 5.1 processing stream (Fischl et al., 2002) and the Desikan-Killiany parcellation (Desikan et al., 2006). There was no significant effect of scanner type on PIB retention $\left(t_{(116)}=0.59, p=0.55\right)$.

\section{Assessment of the APOE genotype}

The APOE genotyping was performed using DNA obtained from blood samples and results were dichotomized into APOE $\varepsilon 4$ allele carrier $(\mathrm{ApoE} 4+)$ or noncarrier (ApoE4-) status. Thirty-three participants (28\%) had a least one APOE $\varepsilon 4$ allele, with two (2\%) homozygous APOE $\varepsilon 4$ carriers.

\section{Statistical analysis}

All statistical analyses were performed using SPSS. Statistical significance was defined as $p<0.05$, two-tailed. Hierarchical regression models with ordinary least-squares estimation were performed. Main effects and interactions between APOE $\varepsilon 4$ carrier status (dummy-coded independent 
Table 2. Hierarchical regression models for APOE $\epsilon 4$ carrier status, lifetime cognitive activity, and cortical PIB retention

\begin{tabular}{|c|c|c|c|c|c|c|}
\hline \multirow[b]{2}{*}{ Models } & \multicolumn{2}{|c|}{$\begin{array}{l}\text { Unstandardized } \\
\text { coefficients }\end{array}$} & \multirow{2}{*}{$\begin{array}{l}\text { Standardized coefficients } \\
\text { Beta }\end{array}$} & \multirow[b]{2}{*}{$\Delta \mathrm{R} 2$} & \multicolumn{2}{|l|}{ Correlations } \\
\hline & $B$ & SE & & & Zero-order & Partial \\
\hline Model adjusted for age, gende & & & & & & \\
\hline Main effect level & & & & $0.21^{* * *}$ & & \\
\hline APOE $\epsilon 4$ carrier status $^{b}$ & $0.82^{* * *}$ & 0.18 & $0.38^{* * *}$ & & 0.38 & 0.39 \\
\hline CA, lifetime & $-0.25^{* *}$ & 0.08 & $-0.25^{* *}$ & & -0.25 & -0.27 \\
\hline Interaction effect level & & & & $0.04^{*}$ & & \\
\hline Main effect level & & & & $0.21^{* * *}$ & & \\
\hline APOE $\epsilon 4$ carrier status $^{b}$ & $0.82^{* * *}$ & 0.18 & $0.38^{* * *}$ & & 0.38 & 0.39 \\
\hline CA, lifetime & $-0.24^{* *}$ & 0.08 & $-0.24^{* *}$ & & -0.25 & -0.26 \\
\hline Interaction effect level & & & & $0.04^{*}$ & & \\
\hline ApoE4 $\times$ CA, lifetime & $-0.47^{*}$ & 0.19 & $-0.23^{*}$ & & & \\
\hline \multicolumn{7}{|c|}{ Model additionally adjusted for depression ${ }^{a}$} \\
\hline ApoE4 $\times$ CA, lifetime & $-0.44^{*}$ & 0.19 & $-0.22^{*}$ & & & \\
\hline \multicolumn{7}{|c|}{ Model additionally adjusted for current physical activity ${ }^{a}$} \\
\hline Main effect level & & & & $0.20^{* * *}$ & & \\
\hline $\mathrm{APOE} \in 4$ carrier status $^{b}$ & $0.82^{* * *}$ & 0.18 & $0.38^{* * *}$ & & 0.38 & 0.39 \\
\hline CA, lifetime & $-0.23^{* *}$ & 0.08 & $-0.23^{* *}$ & & -0.24 & -0.25 \\
\hline Interaction effect level & & & & $0.03+$ & & \\
\hline ApoE4 $\times$ CA, lifetime & $-0.37+$ & 0.19 & $-0.18+$ & & & \\
\hline \multicolumn{7}{|c|}{ Model additionally adjusted for socioeconomic status ${ }^{a}$} \\
\hline Main effect level & & & & $0.20^{* * *}$ & & \\
\hline $\mathrm{APOE} \in 4$ carrier status $^{b}$ & $0.82^{* * *}$ & 0.18 & $0.38^{* * *}$ & & 0.38 & 0.39 \\
\hline CA, lifetime & $-0.23^{* *}$ & 0.08 & $-0.23^{* *}$ & & -0.24 & -0.25 \\
\hline Interaction effect level & & & & $0.02+$ & & \\
\hline ApoE4 $\times$ CA, lifetime & $-0.36+$ & 0.20 & $-0.17+$ & & & \\
\hline
\end{tabular}

${ }^{a}$ Dependent variable: cortical $\mathrm{PIB}$ retention.

${ }^{b} \mathrm{APOE} \epsilon 4$ carrier status: dummy coded with carriers $=1$, noncarriers $=0$.

${ }^{* * *} p<0.001,{ }^{* *} p<0.01,{ }^{*} p<0.05,+p<0.1$ (trend).

$C A$, Cognitive activity; $\Delta$, difference.

variable: ApoE4 $+=1$, ApoE4 $-=0$ ) and lifetime cognitive activity (continuous independent variables) on cortical PIB retention (continuous dependent variable) were examined. APOE $\varepsilon 4$ carrier status and lifetime cognitive activity were entered at first level of the hierarchical regression model. The interaction between APOE $\varepsilon 4$ carrier status and lifetime cognitive activity was entered at second level. At each level, the unique change in explained variance $\left(R^{2}\right)$ was evaluated using $F$-ratio statistics. For each regression model, standardized residuals $(\geq 3 \mathrm{SD})$ and Mahalanobis Distance $(\geq 20)$ were inspected. Unless reported otherwise, significant results remained unchanged when outliers and influential cases were removed from the original dataset and the analyses rerun. Analyses were adjusted for age, gender, and years of education as done previously (Wilson et al., 2003; Landau et al., 2012). Adjustments were done by using the standardized regression residuals of lifetime cognitive activity and cortical PIB retention after regression on age, gender, and years of education.

Simple slope analyses were conducted to interpret the directionality of significant interactive effects (Aiken and West, 1991; Cohen et al., 2003). First, the interaction was visualized and evaluated descriptively as follows: Observed cortical PIB retention (mean-centered) was graphed as a function of APOE carrier status and lifetime cognitive activity (meancentered). In addition, predicted global and voxelwise cortical PIB retention scores were calculated for low ( -1 SD of the mean) and high (+1 SD of the mean) lifetime cognitive activity using the unstandardized regression coefficients and graphed. Second, we formally examined whether the relationship between lifetime cognitive activity and PIB retention differed significantly from zero in APOE $\varepsilon 4$ carriers. The APOE genotype variable was dummy-coded (ApoE4 $+=0, \mathrm{ApoE} 4-=1)$, so that the regression coefficient of lifetime cognitive activity could be used to assess the relationship between lifetime cognitive activity and PIB retention within $\varepsilon 4$ carriers in the hierarchical regression model with an interactive term. In follow-up hierarchical regression models and simple slopes analyses (each adjusted for age, gender, and years of education), we also assessed contributions of different age epochs, namely early, middle, and current life cognitive activity.

In a series of analyses, we investigated whether our results remained stable when controlling for perceived memory function, depression, current physical activity, or socioeconomic status. This was done by additional adjustments of cortical PIB retention and cognitive activity measures for these variables (one at a time) and submission of the residuals to hierarchical regression models. The covariates were not significantly associated with cortical PIB retention (all $p>0.05$ ); nevertheless, the analyses were conducted to elaborate potential influences of these variables that could bias the associations we detected.

\section{Results}

The APOE $\varepsilon 4$ carriers did not differ significantly from noncarriers in demographic characteristics, time intervals between neuroimaging and neuropsychological measurements, as well as reported cognitive activity (Table 1 ). Lifetime (and age epochrelated) cognitive activity measures were not significantly correlated with age, gender, years of education, subjective memory function, depression, current physical activity, and socioeconomic status (all $p>0.05$, data not shown). Further, there were no significant associations between cognitive activity and vascular risk factors (i.e., diabetes, hyperlipidemia, and hypertension; all $p>0.05$, data not shown) assessed using $t$ tests over all life epochs. 
A

B
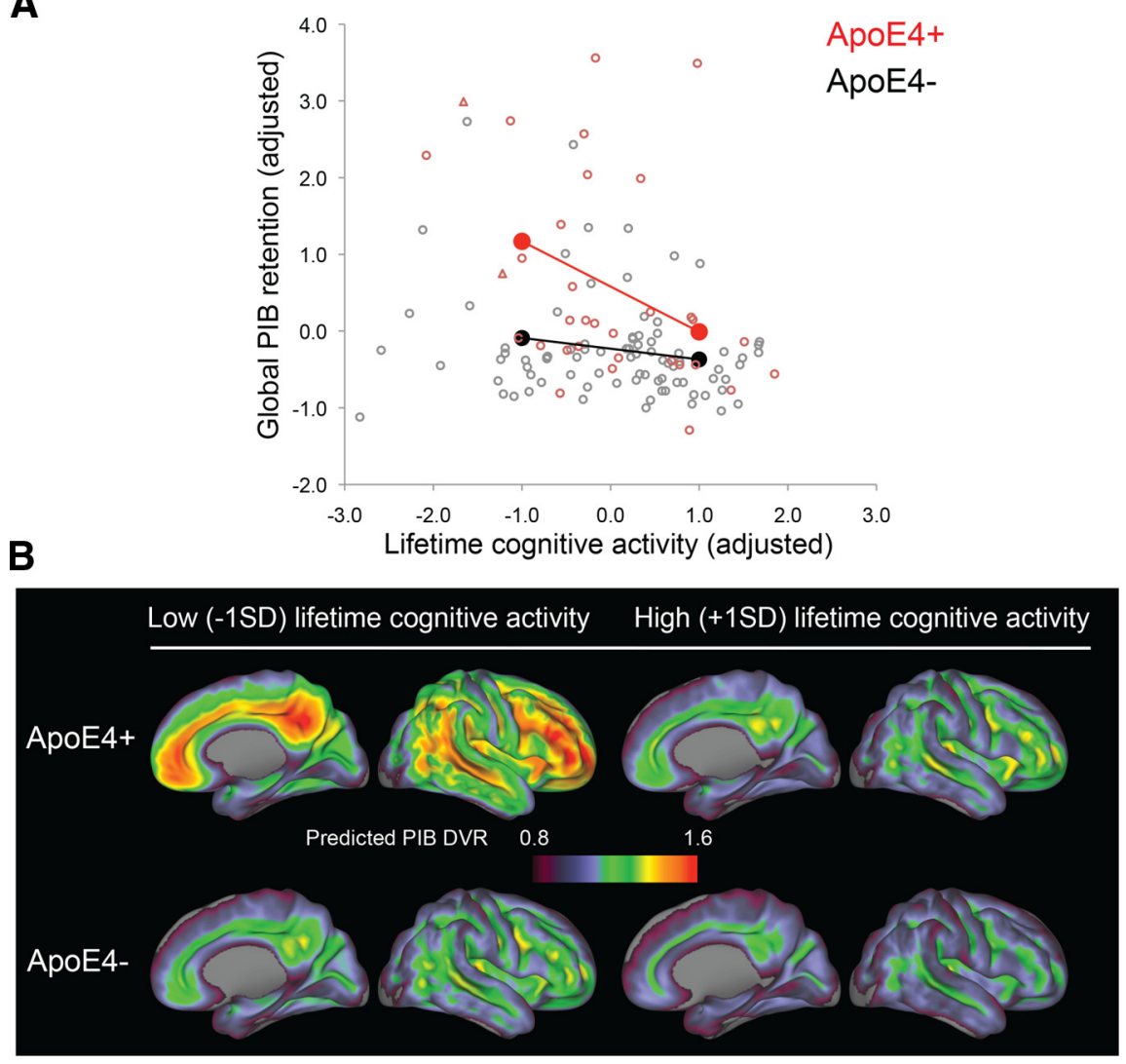

Figure 1. Visualization of the significant interaction between APOE $\varepsilon 4$ carrier status (ApoE4+,ApoE4-) and lifetime cognitive activity. $\boldsymbol{A}, \boldsymbol{B}$, Figures demonstrate that cortical PIB retention is reduced in $\varepsilon 4$ carriers with greater lifetime cognitive activity. $\boldsymbol{A}$, The graph conceptualizes APOE $\varepsilon 4$ carrier status as moderator variable and shows predicted cortical PIB retention (solid circles) in $\varepsilon 4$ carriers (red) and noncarriers (black) for low- and high-lifetime cognitive activity; lines demonstrate linear trends. In addition, observed cortical PIB retention is depicted for heterozygous $\varepsilon 4$ carriers (red circles), homozygous $\varepsilon 4$ carriers (red triangles) and noncarriers (gray circles). Variables are residuals after adjusting for age, gender, and years of education. $\boldsymbol{B}$, Predicted voxelwise cortical PIB retention in $\varepsilon 4$ carriers and noncarriers for low- and high-lifetime cognitive activity (adjusted).

The hierarchical regression model (adjusted for age, gender, and years of education) confirmed increased cortical PIB retention in $\varepsilon 4$ carriers $(p<0.001$; Table 2$)$. Greater lifetime cognitive activity across all subjects was related to lower PIB retention $(p<$ 0.001 ; Table 2). There was a significant interaction between APOE $\varepsilon 4$ carrier status and lifetime cognitive activity $(p<0.05$; Table 2). Simple slope analysis corroborated that higher lifetime cognitive activity mitigated cortical PIB retention specifically in $\varepsilon 4$ carriers $(\mathrm{B}=-0.59, \mathrm{SE}=0.17, \beta=-0.59, p<0.001$; Fig. $1 A, B)$.

In follow-up models, higher lifetime cognitive activity remained significantly associated with lower PIB retention in $\varepsilon 4$ carriers when adjusted for perceived memory function $(\mathrm{B}=$ $-0.60, \mathrm{SE}=0.17, \beta=-0.60, p<0.001)$, depression $(\mathrm{B}=$ $-0.58, \mathrm{SE}=0.17, \beta=-0.58, p<0.001)$, current physical activity $(\mathrm{B}=-0.52, \mathrm{SE}=0.17, \beta=-0.52, p<0.01)$, and socioeconomic status $(\mathrm{B}=-0.51, \mathrm{SE}=0.17, \beta=-0.51, p<0.01)$. The interaction between genotype and cognitive activity was maintained after adjustment for perceived memory function $(p<$ 0.05 ; Table 2) and depression ( $p<0.05$; Table 2$)$, but was reduced to trend level for current physical activity $(p=0.055$; Table 2) and socioeconomic status ( $p=0.067$; Table 2$)$.

Follow-up hierarchical regression models (adjusted for age, gender, and years of education) explored the contribution of different age epochs. The APOE $\varepsilon 4$ carrier status significantly interacted with early life $(\mathrm{B}=-0.42, \mathrm{SE}=0.20, \beta=-0.20$, $p<0.05)$ and middle life $(\mathrm{B}=-0.65, \mathrm{SE}=$ $0.20, \beta=-0.30, p<0.01)$, but not current $(\mathrm{B}=-0.10, \mathrm{SE}=0.19, \beta=-0.06, p=$ $0.58)$ cognitive activity to modulate cortical PIB retention. Simple slope analyses corroborated that higher cognitive activity was significantly related to lower PIB retention in $\varepsilon 4$ carriers for early life ( $\mathrm{B}=$ $-0.55, \mathrm{SE}=0.17, \beta=-0.55, p<0.01)$ and middle life $(\mathrm{B}=-0.77, \mathrm{SE}=0.17$, $\beta=-0.77, p<0.001)$ cognitive activity; the effect was not significant for current cognitive activity $(\mathrm{B}=-0.18, \mathrm{SE}=0.16$, $\beta=-0.18, p=0.25)$. Accounting for the contribution of current cognitive activity, the gene-environment interaction was reduced to trend level for early life ( $\mathrm{B}=$ $-0.38, \mathrm{SE}=0.19, \beta=-0.19, p=0.052$ ) and remained significant for middle life $(\mathrm{B}=-0.50, \mathrm{SE}=0.18, \beta=-0.28, p<$ $0.01)$.

Adjustment for perceived memory function and depression did not change the results. Early life cognitive activity remained significantly associated with PIB retention in $\varepsilon 4$ carriers accounting for current physical activity $(\mathrm{B}=-0.48$, $\mathrm{SE}=0.17, \beta=-0.48, p<0.01)$ and socioeconomic status $(\mathrm{B}=-0.49, \mathrm{SE}=$ $0.18, \beta=-0.49, p<0.01)$; the interactions with APOE $\varepsilon 4$ carrier status were reduced to trend level $(\mathrm{B}=-0.36, \mathrm{SE}=$ $0.20, \beta=-0.17, p=0.073$ and $\mathrm{B}=$ $-0.35, \mathrm{SE}=0.20, \beta=-0.17, p=0.082$, respectively). The other age epoch-related results remained unchanged (data not shown).

\section{Discussion}

Lifetime cognitive engagement appears to have potential for the prevention of AD (Wilson et al., 2002a,b; Barnes and Yaffe, 2011) and may benefit cognitive aging by mitigating $\mathrm{AD}$ pathogenic processes (Landau et al., 2012). The present findings demonstrate that associations between lifetime cognitive activity and $\mathrm{AD}$ pathogenesis are amplified in carriers of the APOE $\varepsilon 4$ allele. The data suggest that lifetime cognitive activity could help to forestall the deleterious impact of the APOE $\varepsilon 4$ allele on brain A $\beta$ deposition.

The presence of at least one APOE $\varepsilon 4$ allele was significantly related to higher brain $\mathrm{A} \beta$ deposition in our data, mirroring previous reports (Reiman et al., 2009; Vemuri et al., 2010; Head et al., 2012). Lifetime cognitive activity, however, interacted with the APOE $\varepsilon 4$ carrier status to modulate $\mathrm{A} \beta$ pathology. Specifically, higher cognitive activity correlated with lower $A \beta$-plaque burden particularly in $\varepsilon 4$ carriers. In a highly comparable way, selfreported long-term physical activity, as well as vascular risk factors, were more strongly related to $\mathrm{A} \beta$ deposition in APOE $\varepsilon 4$ carriers (Head et al., 2012; Brown et al., 2013; Rodrigue et al., 2013). These findings indicate that individuals with genetic risk could be more susceptible to both protective factors and risk factors. There was no significant effect of lifetime cognitive activity in the noncarriers, which is in agreement with prior studies 
likewise reporting the absence of effects of lifestyle and vascular risk on cortical $\mathrm{A} \beta$ deposition in noncarriers (Head et al., 2012; Brown et al., 2013; Rodrigue et al., 2013). A lower proportion of individuals with $\mathrm{A} \beta$ among the noncarriers may have made it difficult to detect smaller effects of lifestyle, although the absolute number of carriers and noncarriers with high $\mathrm{A} \beta$-plaque levels was comparable in the present study. There also could be beneficial effects of cognitive engagement in noncarriers using other biomarker outcomes. This is suggested by findings showing that cognitive activity or training can improve brain function and structure in older adults (Lövdén et al., 2010; Anguera et al., 2013). Nevertheless, our and other studies (Kivipelto et al., 2008; Head et al., 2012) imply that a healthy lifestyle could be particularly protective against $\mathrm{AD}$ in $\varepsilon 4$ carriers.

Our data also imply that an active lifestyle over extended and potentially critical life periods (perhaps starting before $\mathrm{A} \beta$ accumulation) could protect against elevated brain $\mathrm{A} \beta$ burden and thus offset detrimental effects of the APOE polymorphism. Similarly, an earlier study found that long-term physical activity initiated during middle life lowered $\mathrm{A} \beta$ deposition specifically in APOE $\varepsilon 4$ carriers (Head et al., 2012). Animal studies have further shown that both preventative and therapeutic exposure to enriched environments can mitigate $\mathrm{A} \beta$ pathology (in transgenic $\mathrm{A} \beta$-expressing mice) or protect against $\mathrm{A} \beta$-related synaptotoxic effects (in wild-type mice) in experimental compared with control animals (Lazarov et al., 2005; Costa et al., 2007; Herring et al., 2011; Li et al., 2013). A previous report that evaluated lifestyle factors has failed to detect beneficial effects of cognitive activity on $\mathrm{A} \beta$ burden (Vemuri et al., 2012). This might be explained by different study and sample characteristics. In contrast to our study, Vemuri et al. (2012) examined a mixed sample of cognitively normal individuals, as well as mild cognitive impairment patients. Moreover, the cognitive activity measure was constructed of education, occupation and current cognitive activity, whereas the present cognitive activity interview examined the frequency of cognitive activities over the life span (Wilson et al., 2003). It is also possible that effects of cognitive activity, APOE genotype, and $\mathrm{A} \beta$ might be influenced by the timing of the lifestyle events in relationship to the life course.

At least two biological mechanisms might underlie the observed effects. Rodent models have suggested that beneficial effects of enriched environments directly operate via $\mathrm{A} \beta$ dependent pathways, such as alterations in $\mathrm{A} \beta$ catabolism (Lazarov et al., 2005; Costa et al., 2007). On the other hand, effects of a cognitively demanding lifestyle could also be mediated by neuronal factors. There is indication that higher neural activity promotes $A \beta$ secretion in animals (Bero et al., 2011) and humans (Brody et al., 2008). Lifelong cognitive activity might thus nurture efficiency in neural systems (Jagust and Mormino, 2011; Gold et al., 2013), which could modulate neural activity and thereby attenuate $A \beta$ secretion and accumulation, suggested to begin after the age of 50 (Kok et al., 2009). In young and middleage APOE $\varepsilon 4$ carriers, greater brain activation (Filippini et al., 2009) and lower resting state glucose metabolism (Reiman et al., 2004) has been reported in brain regions susceptible to $\mathrm{A} \beta$ burden. Such neuronal insufficiencies could make beneficial lifestyle factors specifically effective in APOE $\varepsilon 4$ carriers in a manner similar to "cognitive training," improving neural efficiency that could prevent otherwise elevated brain $\mathrm{A} \beta$ deposition in the genetically susceptible individuals.

Our findings converge with recent epidemiological reports, indicating greater effects of lifestyle factors in $\varepsilon 4$ carriers. In particular, middle-life cognitive activity was protective in individu- als with genetic susceptibility (Carlson et al., 2008). Another study indicated that nonbeneficial lifestyle behaviors, such as physical inactivity, high dietary fat intake, alcohol drinking, and smoking were associated with greater risk of dementia and $\mathrm{AD}$ especially among $\varepsilon 4$ carriers (Kivipelto et al., 2008). Our study directly adds to this picture suggesting that lifelong engagement in cognitively stimulating activities could diminish $\mathrm{A} \beta$ aggregation particularly in APOE $\varepsilon 4$ carriers. Cognitive activity could thereby be beneficial, especially when individuals engage over extended life periods, starting well before $\mathrm{A} \beta$ deposition emerges.

The present study is relatively small in sample size, thus the gene-environment relationship on $\mathrm{AD}$ pathology needs to be further investigated and replicated in larger cohorts. Our results are based on self-reports, some of which are retrospective. Though we have used a reliable and previously validated cognitive activity questionnaire, it is possible that the current cognitive status and health status of older individuals (in particular with genetic risk and $\mathrm{A} \beta$ pathology) could bias self-reported evaluations of past cognitive activity. This explanation does not seem likely because results remained stable after additional adjustments for subjective memory function and depression. However, it is still possible that an undetected bias influenced participants' responses and therefore the relationships we detected. Adjustment for current physical activity and socioeconomic status somewhat influenced the interactive effects between cognitive activity and APOE status. This might be attributable to statistical power, because associations between cognitive activity and brain $\mathrm{A} \beta$ burden within $\varepsilon 4$ carriers were unaffected. The results seen here can best be confirmed by either a prospective study or randomized intervention.

The results are part of a growing literature indicating beneficial effects of lifestyle factors in reducing the risk of cognitive decline and $\mathrm{AD}$ development. The present findings suggest that cognitive activity could modify heightened $\mathrm{A} \beta$-plaque accumulation in carriers of the APOE $\varepsilon 4$ allele, a major genetic risk factor for AD. This importance of lifelong health behaviors, specifically in individuals with genetic susceptibility, has essential implications for public health approaches to AD risk reduction, in particular in the absence of effective treatments.

\section{References}

Aiken LS, West SG (1991) Multiple regression: testing and interpreting interactions. Newbury Park, CA: Sage Publications.

Anguera JA, Boccanfuso J, Rintoul JL, Al-Hashimi O, Faraji F, Janowich J, Kong E, Larraburo Y, Rolle C, Johnston E, Gazzaley A (2013) Video game training enhances cognitive control in older adults. Nature 501:97101. CrossRef Medline

Barnes DE, Yaffe K (2011) The projected effect of risk factor reduction on Alzheimer's disease prevalence. Lancet Neurol 10:819-828. CrossRef Medline

Bero AW, Yan P, Roh JH, Cirrito JR, Stewart FR, Raichle ME, Lee JM, Holtzman DM (2011) Neuronal activity regulates the regional vulnerability to amyloid-beta deposition. Nat Neurosci 14:750-756. CrossRef Medline

Brody DL, Magnoni S, Schwetye KE, Spinner ML, Esparza TJ, Stocchetti N, Zipfel GJ, Holtzman DM (2008) Amyloid-beta dynamics correlate with neurological status in the injured human brain. Science 321:1221-1224. CrossRef Medline

Brown BM, Peiffer JJ, Taddei K, Lui JK, Laws SM, Gupta VB, Taddei T, Ward VK, Rodrigues MA, Burnham S, Rainey-Smith SR, Villemagne VL, Bush A, Ellis KA, Masters CL, Ames D, Macaulay SL, Szoeke C, Rowe CC, Martins RN (2013) Physical activity and amyloid-beta plasma and brain levels: results from the Australian imaging, biomarkers and lifestyle study of ageing. Mol Psychiatry 18:875-881. CrossRef Medline

Carlson MC, Helms MJ, Steffens DC, Burke JR, Potter GG, Plassman BL (2008) Midlife activity predicts risk of dementia in older male twin pairs. Alzheimers Dement 4:324-331. CrossRef Medline

Cohen J, Cohen P, West SG, Aiken LS (2003) Applied multiple regression/ 
correlation analysis for the behavioral sciences, Ed 3. Mahwah, NJ: L. Erlbaum Associates.

Costa DA, Cracchiolo JR, Bachstetter AD, Hughes TF, Bales KR, Paul SM, Mervis RF, Arendash GW, Potter H (2007) Enrichment improves cognition in AD mice by amyloid-related and unrelated mechanisms. Neurobiol Aging 28:831-844. CrossRef Medline

Desikan RS, Ségonne F, Fischl B, Quinn BT, Dickerson BC, Blacker D, Buckner RL, Dale AM, Maguire RP, Hyman BT, Albert MS, Killiany RJ (2006) An automated labeling system for subdividing the human cerebral cortex on MRI scans into gyral based regions of interest. Neuroimage 31:968980. CrossRef Medline

Farrer LA, Cupples LA, Haines JL, Hyman B, Kukull WA, Mayeux R, Myers RH, Pericak-Vance MA, Risch N, van Duijn CM (1997) Effects of age, sex, and ethnicity on the association between apolipoprotein E genotype and Alzheimer disease: a meta-analysis. JAMA 278:1349-1356. CrossRef Medline

Filippini N, MacIntosh BJ, Hough MG, Goodwin GM, Frisoni GB, Smith SM, Matthews PM, Beckmann CF, Mackay CE (2009) Distinct patterns of brain activity in young carriers of the APOE-epsilon4 allele. Proc Natl Acad Sci U S A 106:7209-7214. CrossRef Medline

Fischl B, Salat DH, Busa E, Albert M, Dieterich M, Haselgrove C, van der Kouwe A, Killiany R, Kennedy D, Klaveness S, Montillo A, Makris N, Rosen B, Dale AM (2002) Whole brain segmentation: automated labeling of neuroanatomical structures in the human brain. Neuron 33:341355. CrossRef Medline

Geffken DF, Cushman M, Burke GL, Polak JF, Sakkinen PA, Tracy RP (2001) Association between physical activity and markers of inflammation in a healthy elderly population. Am J Epidemiol 153:242-250. CrossRef Medline

Gold BT, Kim C, Johnson NF, Kryscio RJ, Smith CD (2013) Lifelong bilingualism maintains neural efficiency for cognitive control in aging. J Neurosci 33:387-396. CrossRef Medline

Hauser RM, Warren JR (1997) Socioeconomic indexes for occupations: a review, update, and critique. Soc Methodol 27:177-298. CrossRef

Head D, Bugg JM, Goate AM, Fagan AM, Mintun MA, Benzinger T, Holtzman DM, Morris JC (2012) Exercise engagement as a moderator of the effects of APOE genotype on amyloid deposition. Arch Neurol 69:636643. CrossRef Medline

Herring A, Lewejohann L, Panzer AL, Donath A, Kröll O, Sachser N, Paulus W, Keyvani K (2011) Preventive and therapeutic types of environmental enrichment counteract beta amyloid pathology by different molecular mechanisms. Neurobiol Dis 42:530-538. CrossRef Medline

Jack CR Jr, Knopman DS, Jagust WJ, Shaw LM, Aisen PS, Weiner MW, Petersen RC, Trojanowski JQ (2010) Hypothetical model of dynamic biomarkers of the Alzheimer's pathological cascade. Lancet Neurol 9:119-128. CrossRef Medline

Jagust WJ, Mormino EC (2011) Lifespan brain activity, beta-amyloid, and Alzheimer's disease. Trends Cogn Sci 15:520-526. CrossRef Medline

Kivipelto M, Rovio S, Ngandu T, Kåreholt I, Eskelinen M, Winblad B, Hachinski V, Cedazo-Minguez A, Soininen H, Tuomilehto J, Nissinen A (2008) Apolipoprotein E epsilon4 magnifies lifestyle risks for dementia: a population-based study. J Cell Mol Med 12:2762-2771. CrossRef Medline

Kok E, Haikonen S, Luoto T, Huhtala H, Goebeler S, Haapasalo H, Karhunen PJ (2009) Apolipoprotein E-dependent accumulation of Alzheimer disease-related lesions begins in middle age. Ann Neurol 65:650-657. CrossRef Medline

Landau SM, Marks SM, Mormino EC, Rabinovici GD, Oh H, O’Neil JP, Wilson RS, Jagust WJ (2012a) Association of lifetime cognitive engagement and low beta-amyloid deposition. Arch Neurol 69:623-629. CrossRef Medline

Lazarov O, Robinson J, Tang YP, Hairston IS, Korade-Mirnics Z, Lee VM, Hersh LB, Sapolsky RM, Mirnics K, Sisodia SS (2005) Environmental enrichment reduces Abeta levels and amyloid deposition in transgenic mice. Cell 120:701-713. CrossRef Medline

Liang KY, Mintun MA, Fagan AM, Goate AM, Bugg JM, Holtzman DM, Morris JC, Head D (2010) Exercise and Alzheimer's disease biomarkers in cognitively normal older adults. Ann Neurol 68:311-318. CrossRef Medline

Li S, Jin M, Zhang D, Yang T, Koeglsperger T, Fu H, Selkoe DJ (2013) Environmental novelty activates beta2-adrenergic signaling to prevent the impairment of hippocampal LTP by Abeta oligomers. Neuron 77:929941. CrossRef Medline
Logan J, Fowler JS, Volkow ND, Wang GJ, Ding YS, Alexoff DL (1996) Distribution volume ratios without blood sampling from graphical analysis of PET data. J Cereb Blood Flow Metab 16:834-840. CrossRef Medline

Lövdén M, Bodammer NC, Kühn S, Kaufmann J, Schütze H, Tempelmann C, Heinze HJ, Düzel E, Schmiedek F, Lindenberger U (2010) Experiencedependent plasticity of white-matter microstructure extends into old age. Neuropsychologia 48:3878-3883. CrossRef Medline

Niti M, Yap KB, Kua EH, Tan CH, Ng TP (2008) Physical, social and productive leisure activities, cognitive decline and interaction with APOEepsilon 4 genotype in Chinese older adults. Int Psychogeriatr 20:237-251. CrossRef Medline

Packard CJ, Westendorp RG, Stott DJ, Caslake MJ, Murray HM, Shepherd J, Blauw GJ, Murphy MB, Bollen EL, Buckley BM, Cobbe SM, Ford I, Gaw A, Hyland M, Jukema JW, Kamper AM, Macfarlane PW, Jolles J, Perry IJ, Sweeney BJ, Twomey C, et al. (2007) Association between apolipoprotein $\mathrm{E} 4$ and cognitive decline in elderly adults. J Am Geriatr Soc 55:17771785. CrossRef Medline

Perrotin A, Mormino EC, Madison CM, Hayenga AO, Jagust WJ (2012) Subjective cognition and amyloid deposition imaging: a Pittsburgh compound B positron emission tomography study in normal elderly individuals. Arch Neurol 69:223-229. CrossRef Medline

Reiman EM, Chen K, Alexander GE, Caselli RJ, Bandy D, Osborne D, Saunders AM, Hardy J (2004) Functional brain abnormalities in young adults at genetic risk for late-onset Alzheimer's dementia. Proc Natl Acad Sci U S A 101:284-289. CrossRef Medline

Reiman EM, Chen K, Liu X, Bandy D, Yu M, Lee W, Ayutyanont N, Keppler J, Reeder SA, Langbaum JB, Alexander GE, Klunk WE, Mathis CA, Price JC, Aizenstein HJ, DeKosky ST, Caselli RJ (2009) Fibrillar amyloid-beta burden in cognitively normal people at 3 levels of genetic risk for Alzheimer's disease. Proc Natl Acad Sci U S A 106:6820-6825. CrossRef Medline

Rodrigue KM, Rieck JR, Kennedy KM, Devous MD Sr, Diaz-Arrastia R, Park DC (2013) Risk factors for beta-amyloid deposition in healthy aging: vascular and genetic effects. JAMA Neurol 70:600-606. CrossRef Medline

Taylor HL, Jacobs DR Jr, Schucker B, Knudsen J, Leon AS, Debacker G (1978) A questionnaire for the assessment of leisure time physical activities. J Chronic Dis 31:741-755. CrossRef Medline

Vemuri P, Wiste HJ, Weigand SD, Knopman DS, Shaw LM, Trojanowski JQ, Aisen PS, Weiner M, Petersen RC, Jack CR Jr (2010) Effect of apolipoprotein $\mathrm{E}$ on biomarkers of amyloid load and neuronal pathology in Alzheimer disease. Ann Neurol 67:308-316. CrossRef Medline

Vemuri P, Lesnick TG, Przybelski SA, Knopman DS, Roberts RO, Lowe VJ, Kantarci K, Senjem ML, Gunter JL, Boeve BF, Petersen RC, Jack CR Jr (2012) Effect of lifestyle activities on Alzheimer disease biomarkers and cognition. Ann Neurol 72:730-738. CrossRef Medline

Wilson RS, Mendes De Leon CF, Barnes LL, Schneider JA, Bienias JL, Evans DA, Bennett DA (2002a) Participation in cognitively stimulating activities and risk of incident Alzheimer disease. JAMA 287:742-748. CrossRef Medline

Wilson RS, Bennett DA, Bienias JL, Aggarwal NT, Mendes De Leon CF, Morris MC, Schneider JA, Evans DA (2002b) Cognitive activity and incident $\mathrm{AD}$ in a population-based sample of older persons. Neurology 59:1910-1914. CrossRef Medline

Wilson RS, Segawa E, Boyle PA, Bennett DA (2012) Influence of late-life cognitive activity on cognitive health. Neurology 78:1123-1129. CrossRef Medline

Wilson R, Barnes L, Bennett D (2003) Assessment of lifetime participation in cognitively stimulating activities. J Clin Exp Neuropsychol 25:634642. CrossRef Medline

Wirth M, Madison CM, Rabinovici GD, Oh H, Landau SM, Jagust WJ (2013) Alzheimer's disease neurodegenerative biomarkers are associated with decreased cognitive function but not beta-amyloid in cognitively normal older individuals. J Neurosci 33:5553-5563. CrossRef Medline

Woodard JL, Sugarman MA, Nielson KA, Smith JC, Seidenberg M, Durgerian S, Butts A, Hantke N, Lancaster M, Matthews MA, Rao SM (2012) Lifestyle and genetic contributions to cognitive decline and hippocampal structure and function in healthy aging. Curr Alzheimer Res 9:436-446. CrossRef Medline

Yesavage JA, Brink TL, Rose TL, Lum O, Huang V, Adey M, Leirer VO (1982) Development and validation of a geriatric depression screening scale: a preliminary report. J Psychiatr Res 17:37-49. CrossRef Medline 